\title{
SCORPION ENVENOMATION IN BAGH-E MALEK, IRAN -A 5 YEAR STUDY
}

\author{
M. Ghassemi, M. Banarimehr, D. Bahrami, A. Karimyan, A._Asghar Valipour* \\ Student research committee, Abadan School of Medical Sciences, Abadan, Iran
}

Published online: 15 February 2017

\begin{abstract}
Scorpionism is a major health problem in many tropical countries including Iran. The aim of this study was to describe the epidemiological and demographic information among whom stung by scorpions in Bagh-E Malek, Iran. In this retrospective cross-sectional study the information were gathered through evaluation of the records of stung patients referring to Shahid Tabatabai hospital of Bagh-E Malek April 2008 to April 2012. A total of 132 cases stung by scorpion were recorded including 3115 males (43\%) and 4121 females (57\%).Approximately 42.1 percent of the sting cases occurred in the summer followed by spring with $35.9 \%$ of stings. About $59.8 \%$ of stings happened in people by the age of 15-44 years old. Most of the stings happened in exposed extremities (78.5\%) with most of it in upper limbs (41.8\%). The scorpions' species were unknown but $60.4 \%$ of them were yellow, $34.0 \%$ black and $5.6 \%$ were "other colors". Since the highest rate of scorpionism cases were reported in rural areas $(74.2 \%)$, it is suggested that the main focus should be considered for education of rural people, especially women who play a major role in the family. Additionally, evaluation of residential houses and surrounding environment and giving information on method of cleaning up the environment from the equipment and the factors from which scorpion may use as shelter, can also be effective in reducing the incidence of Scorpionism.
\end{abstract}

Keywords: Scorpion sting; Epidemiology; Bagh-E Malek; Iran

Author Correspondence, e-mail: author@gmail.com

doi: http://dx.doi.org/10.4314/jfas.v9i1s.715 


\section{INTRODUCTION}

Scorpions (Arthropods: Arachnida)are amedically important arthropod which has beendistributed around the world, but usually they are abundant in the warm and dry weather conditions(1). So far, about 1,500 species of scorpions have been reported from all over the world of which only 30 species are medically important (2-5).According to the scientific reports, about 51 species of scorpions have been reported from Iran that belong to four families (Buthidae, Scorpionidae, Hemiscorpiidae, and Diplocentridae) and areclassified in 14 genera.These Scorpionscause 40,000 to 50,000Scorpionisms each yearand approximately 19 deaths happen in Iran which is the highest reported in the Middle East (6-9). The main Scorpionisms in Iran are caused by 3 scorpions including Mesobuthus eupeus (CL Koch, 1839), Androctonus crassicauda (Olivier, 1807), and Hemiscorpius lepturus (Peters, 1861), and the scorpions ofHottentota saulcyi (Simon, 1880), Odontobuthus doriae (Thorell, 1876), Mesobuthus caucasicaus (Nordmann, 1840) and Apistobuthus pterygosercus (Finnegan, $1932)$ are in the next ranks $(2,10)$.

In a retrospective study by Rahman et al.which was conducted in 2015 on 1922 cases of scorpionism in Ahvaz (Khuzestan), it was determined that $56.86 \%$ of the reported people were female and the rest were male while from this population $31.94 \%$ were stungby Hemiscorpius lepturus and others were stung by other scorpions(1). In a retrospective study conducted by Kasiri et al (2015) in Fars,also 58.6\% of stung people were women that were the highest rate (2).

Most of scorpionism and the caused death have been reported inKhuzestan province in southwestern Iran (1563 per 100000 people)and the cities of Masjed Soleiman, Rāmhormoz, izeh, Susa, and Bagh-E malek were respectively ranked as first to fifth in this field(11). Since in the studied city of this research a greater percentage of the population were living in rural areas and also due to the mountainous terrain and climate of the city, dangerous scorpions Hemiscorpius lepturusis certainly present in this region, therefore, it seemed thatdemographic and epidemiological data of stung people in this area is neededto carry out targeted and preventive measures. For this reason, the present study was conducted to assess these characteristics in 7236stungpeople in this city over a period of 5 years.

\section{MATERIALS AND METHODS:}

The present study is a retrospective cross-sectional study, which was conducted during a 5year period from April 2008 to March 2012 and through evaluation of the records of scorpionism patients referring to Shahid Tabatabai hospital of Bagh-E Malek. In terms of 
geographical location,Bagh-E Malek city $\left(31^{\circ} 31\right.$ '23 "N, $\left.49^{\circ} 53^{\prime} 10^{\prime \prime} \mathrm{E}\right)$ is located in the East Khuzestan province (Figure A), with altitude above sea as $917 \mathrm{~m}$ and the population of 20844 people according to the 2006 census. The required data for the research was collected using a questionnaire which is completed for each patient in the hospital.The questionnaire consisted of demographic information, gender, geographic location of residence, the interval between the stingand serum receiving, serum injection method (intramuscular or intravenous) and the situation of injured person after serum injection.All data was analyzed using SPSS software and results less than0.05 $(\mathrm{P}<0.05)$ was considered as significant.

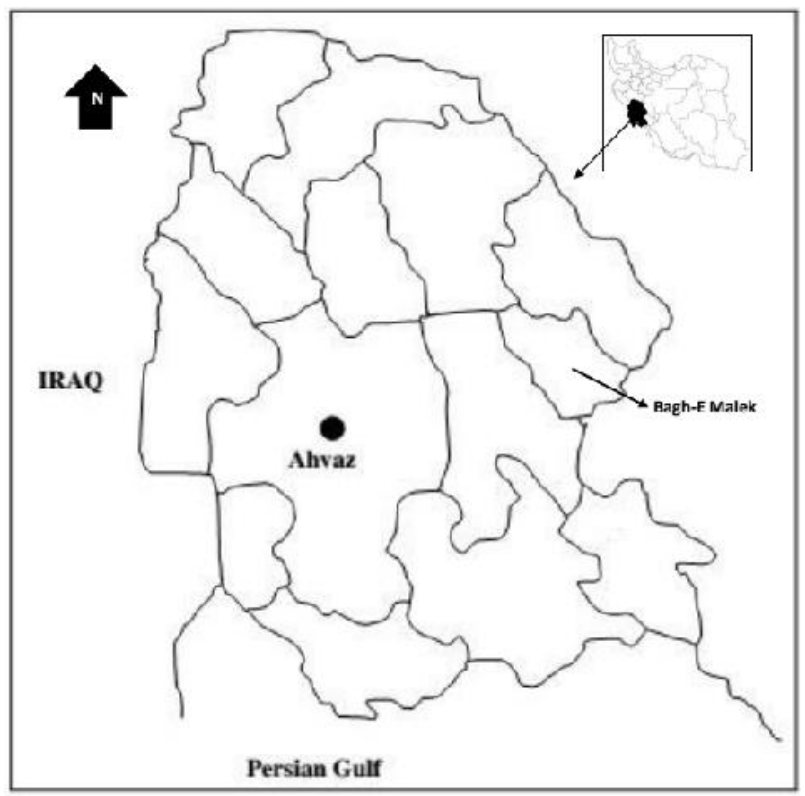

Fig.1. Geographical location of the study site in Khuzestan province of Iran

\section{RESULTS}

The results of this study are reported based on 7236 stung peopole $(57 \%$ female and $43 \%$ male) referring to Shahid Tabatabayi Hospital between the years from 2008 till 2012 in Baghmalek city.

Figure2 shows that statistics of scorpionism in 2008 and 2012 years is almost the same; however, the largest number of scorpionism has occurred in 2012 (23\% of bitten people) and the lowest in 2011 (4.17\% ofstung people).Time dispersion ofscorpionism in the area clearly shows that the number of bites is subject to seasonal changes so that the greatest number of stung people in the summer (42.1\%), especially in August (15.5\%) and then in June (15.3\%) and July (15\%) and the lowest number have been observedin winter (4\%) and in January and March each with $2.1 \%$ (Table1). 


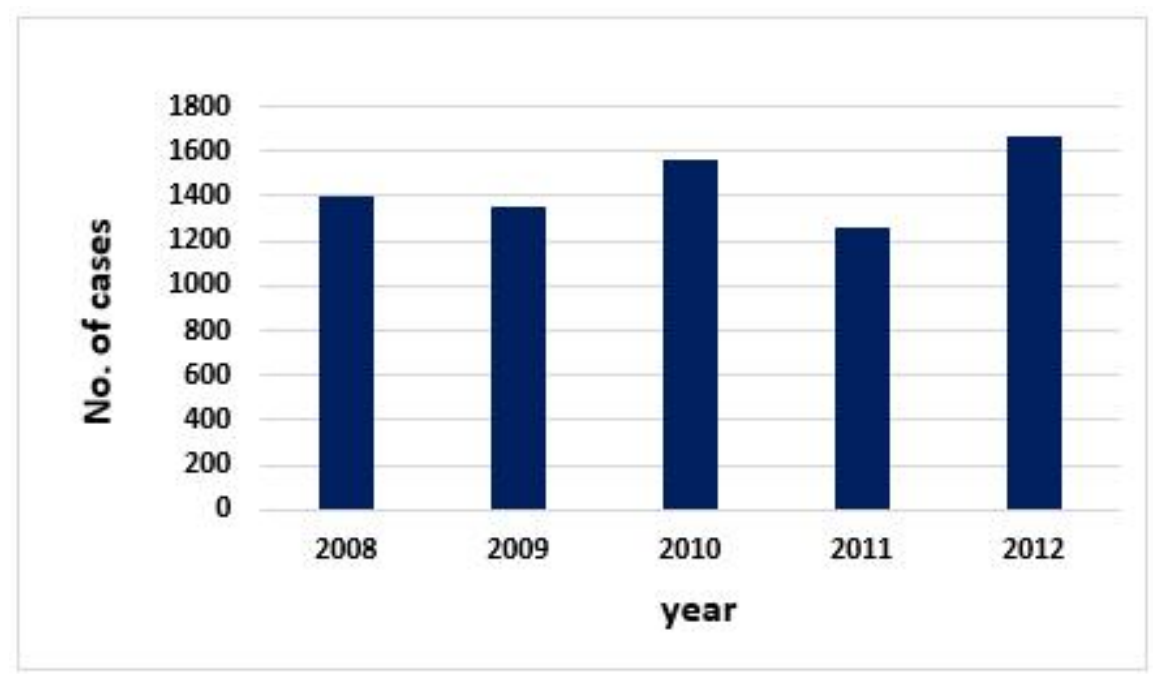

Fig.2. Annual trend of patients with scorpion stings in Bagh-E Malek during 2008 to 2012

Table1. Seasonal frequency of stings in patients with scorpion stings in Bagh-E Malek during 2008 to 2012

\begin{tabular}{llllll}
\hline season & No. & $\%$ & Month & No. & $\%$ \\
\hline Spring & 2599 & 35.9 & April & 537 & 7.4 \\
& & & May & 952 & 13.2 \\
& & & June & 1110 & 15.3 \\
Summer & \multirow{2}{*}{3045} & 42.1 & July & 1083 & 15.0 \\
& & & August & 1115 & 15.4 \\
& & & September & 847 & 11.7 \\
Autumn & \multirow{2}{*}{1301} & \multirow{2}{*}{18.0} & October & 723 & 10.0 \\
& & & November & 472 & 6.5 \\
& & & December & 106 & 1.5 \\
winter & \multirow{2}{*}{291} & 4.0 & January & 84 & 1.2 \\
& & & February & 119 & 1.6 \\
& & & March & 88 & 1.2 \\
\hline
\end{tabular}

Table 2 shows that most stungpeople are in the age group of15-44 years (59.8\%), 1724 patients in the age group of 15- 24 years, 1588 people in the age group of 25 - 34 years, and 1020 patients in the age group of 34-44 years). 
Table 2. The epidemiological variables in patients with scorpion stings in Bagh-E Malek during 2008 to 2012

\begin{tabular}{|c|c|c|}
\hline variable & $\begin{array}{r}\text { Number of patients } \\
(\mathrm{n}: 7236)\end{array}$ & $\%$ \\
\hline Sex & & \\
\hline Female & 4121 & 57 \\
\hline Male & 3115 & 43 \\
\hline \multicolumn{3}{|l|}{ Age group (years) } \\
\hline $0-14$ & 1418 & 19.6 \\
\hline $15-44$ & 4332 & 59.8 \\
\hline$>45$ & 1486 & 20.6 \\
\hline \multicolumn{3}{|l|}{ Site of sting } \\
\hline Upper extremity & 3027 & 41.8 \\
\hline Lower extremity & 2657 & 36.7 \\
\hline Head and trunk & 1552 & 21.4 \\
\hline \multicolumn{3}{|l|}{ Type of scorpions } \\
\hline Yellow & 4370 & 60.4 \\
\hline Black & 2458 & 34.0 \\
\hline Others & 408 & 5.6 \\
\hline \multicolumn{3}{|l|}{$\begin{array}{r}\text { Geographical } \\
\text { distribution }\end{array}$} \\
\hline Urban & 1865 & 25.8 \\
\hline Rural & 5371 & 74.2 \\
\hline
\end{tabular}

The results showed that most stung people lived in rural areas(74.2\%). Analysis of the collected information demonstrated that $24.4 \%$ of women and $27.6 \%$ of men are urban residents while $75.6 \%$ of women and $72.4 \%$ of men are rural residents and this difference was statistically significant $(\mathrm{P}=0.002)$. Additionally, there was a statistically significant difference between the residence locations $(\mathrm{P}=0.000)$ so that most people had a history of being stung in the rural areas.

Most of sting site in body were in the arms (41.8\%) and the lowest number were the head and trunk $(21.4 \%)$. 
According to Table3,51.8\% of examined people had received serum for treatment and none of them showed the shock caused by serum. The applied anti-Venom was injected intramuscularly for $86.09 \%$ and the rest intravenously; the results of analysis revealed that there was statistically significant difference between the percentage of females $(54.1 \%)$ and men $(48.7 \%)$ who received serum $(\mathrm{p}=0.000)$. Additionally there was a significant difference between men and women in terms of the interval between getting stung and serum receiving $(\mathrm{P}=0.000)$ so that $41.1 \%$ of men and $44.7 \%$ of women have received serum within 0 6 hours after being stung.

Table 3: The frequency of different variables regarding to antiserum reception in patients with scorpion stings in Bagh-E Malek during 2008 to 2012

\begin{tabular}{l|l|l}
\hline & No. & $\%$ \\
\hline Antivenom receipt & 3748 & 51.8 \\
Antivenom previous receipt & 87 & 1.2 \\
Antivenom allergy & 0 & 0 \\
& & \\
Elapsed time between sting and & & \\
reciening antivenom (h) & 3122 & 83.3 \\
$<6$ & 53 & 1.4 \\
$6-12$ & 573 & 15.3 \\
$>12$ & & \\
Route of injection & 525 & 14 \\
IV & 3223 & 86 \\
IM & & \\
\hline
\end{tabular}

During the 5-year study,from 7236 stungpeople $99.96 \%$ of people improved and only 3 deaths $(0.04 \%)$ were reportedwhich all were women in the age groups including under 15 years old (one death), 15- 44 years (one person), and greater than 44 years (one death); and from deceased persons, onewas urban resident and two others were rural residents.Studying the relationship between gender of stung people and color of Scorpions, it was found that $60.4 \%$ of patients (60.8\%of women and 59.8\% of men) had been stung by yellow scorpions;33.97\% of patients (33\% of women and $3.35 \%$ of men) by black scorpions and the rest of them had been stungby "other scorpions"' while the difference was statistically significant $(\mathrm{P}=0.013)$. 


\section{DISCUSSION}

Given that approximately 1230000 scorpionism and 3250 leading death have been occurredall over the world and with the knowledge that treatment of scorpionism is complexespecially in terms of the use of anti-venom and required systemic treatments, therefore,scorpionism is one of the major public health problems $(1,2,6,12)$.

In the present study most stungpeople by scorpions were female (57\% vs. $43 \%$ men).There are a lot of studies about scorpionism that have similar results $(1,11,13-15)$.However, in this regard, a number of studied can be found that have achieved different results with the results of the present research and reported that most of the stung people by scorpions were men $(6$, 16-20).

In the present study, most people were in the age group of 15-44 years which suggests that most of the stung people were young people and work force of the community, while similar studies confirmedour findings that represent thatthe active force of our communities are at $\operatorname{risk}(6,13,16-19,21)$.

The study of Shahbazzadeh et al 2009(11) shows that 90\% of reportshave been presented in summer (from April to October).In this study it was observed that stings occur throughout the year but the majority of scorpionismoccur in the summer (42\%). This study and many other studies confirm these results that the majority of stings are in June, July and August(6, 13-16, $18,22)$ but there are also studies that report more numbers of stings in the rainy seasons especially May (7, 20, 21).

The results of this study demonstrated that the majority ofstung subjects were rural residents (74.2\%).Vezirian Zadeh et al., 2013(17) and Karami et al. 2013(13)confirmed these results in their study; however, the reported results in studies of Kasiri et al. 2014(6)and Requzigel et al 2014(19) revealed more reports in urban areas.

The collected data showed that most stings occurred in the upper limbs, here we can find studies with similar results $(6,11,14,20)$ but there are studies that their results contradict the mentioned result and reported that most stings were in the lower limbs and organs $(16,17)$.

The method of administration of applied Venom for treatment of stung people by scorpions was mostly intramuscularly (86.09\%), Karami et al. 2013 (13)and Vezirian Zadeh et al 2013(17)also found similar results but in the study of Kasiriet al. 2014(6) the major antivenom administration method has been reported as IV method.

Although the studied subjects could not identify the genus and species of attacker scorpions; however evaluations revealed that the majority of people were stung by yellow scorpions. These results are consistent with results of other studies conducted in Iran in which 
major attacker were reported as yellow scorpions $(1,11,13)$ but in two studies conducted in Turkey(15) and Saudi Arabia(18) the attacker scorpions were reported as Black Scorpions; this difference may be due to different scorpions of every region.

In general, and based on the results obtained from this study, programs could be planned to educate people at risk to avoid happening the stings.Due to the frequency of stings in the rural than urban areas, the main focus should be considered for education of rural people, especially women who play a major role in the family. Additionally, evaluation of residential houses and surrounding environment and giving information on method of cleaning up the environment from the equipment and the factors from which scorpion may use as shelter, can also be effective in reducing the incidence of Scorpionism.

\section{ACKNOWLEDGMENT}

This research was financially supported by student research committee of Abadan school of medical sciences under grant No: 95ST-0073 with ethicalcode of:

IR.ABADANUMS.REC.1395-126

\section{Conflict of interest:}

The authors have no conflict of interest to disclose.

\section{REFERENCES}

1. Rahmani AH, Forouzandeh H, Kalantar M, Asad-Masjedi N, Alavian Z, Kavarizadeh K. Epidemiological and Clinical Characteristics of Scorpion Stings in Ahwaz, Southwest Iran (2006-2010). International Journal of Medical Toxicology and Forensic Medicine. 2015;5(4):201-6.

2. Kassiri H, Kasiri N, Dianat A. Species composition, sex ratio, geographical distribution, seasonal and monthly activity of scorpions and epidemiological features of scorpionism in Zarrin-dasht County, Fars Province, Southern Iran. Asian Pac J Trop Dis. 2015;5(S1):S99S103.

3. Prendini L, Wheeler WC. Scorpion higher phylogeny and classification, taxonomic anarchy,and standards for peer review in online publishing. Cladistics 2005;21:49.

4. DEHGHANI RA, BIGDELI S. SURVEYING THE HABITATS ON HEMISCORPIUS LEPTURUS SCORPION IN KHUZESTAN PROVINCE (SCORPIONIDASCORPIONIDAE). PAJOUHESH-VA-SAZANDEGI 2007;20(2):7. 
5. Chippaux JP, Goyffon M. Epidemiology of scorpionism: A global appraisal. Acta Trop. 2008;107(2):71-9.

6. Kassiri H, Kasiri A, Kasiri E, Safarpor S, Lotfi M. A hospital-based study on scorpionism in Khorram-Shahr County, Southwestern Iran. Asian J Epidemiol. 2014;7(2):28-35.

7. Mirshamsi O, Sari A, Hosseinie S. History of study and checklist of the scorpion fauna (Arachnida: Scorpiones) of Iran. Progress in Biological Sciences. 2011 1(2):18.

8. Mozaffari E, Sedaghat MM, Sanei Dehkordi A, Akbarzadeh K. Bidiversity and species composition of Scorpions (Arachnida, Scorpiones) in Ilam County, Iran. Journal of Applied Sciences Research. 2013;9(9):8.

9. Dehghani R, Fathi B. Scorpion sting in Iran: a review. Toxicon. 2012;60(5):919-33.

10. Dehghani RM, Sh.; Kamyabi, F.; Haghdoost, A.A.; Mashayekhi, M.; Soltani, H. Scorpions Fauna of Kerman Province-IRAN. Journal of Kerman University of Medical Sciences. 2008 15(2):10.

11. Shahbazzadeh D, Amirkhani A, Djadid ND, Bigdeli S, Akbari A, Ahari H, et al. Epidemiological and clinical survey of scorpionism in Khuzestan province, Iran (2003). Toxicon. 2009;53(4):454-9.

12. Dehgani R, Rabbani D, Hoseindoost G, Mashayekhi M. DEADLY SCORPION HABITATS OF IRAN. Indian Journal of Fundamental and Applied Life Sciences. 2014;4(2):5.

13. Karami K, Vazirianzadeh B, Mashhadi E, Hossienzadeh M, Moravvej SA. A five year epidemiologic study on scorpion stings in Ramhormoz, South-West of Iran. Pak J Zool. 2013;45(2):469-74.

14. Adiguzel S, Ozkan O, Inceoglu B. Epidemiological and clinical characteristics of scorpionism in children in Sanliurfa, Turkey. Toxicon. 2007;49(6):875-80.

15. 1 AB, Yılmaz1 DA, Söğut2 Ö, Orak3 M, Üstündağ3 M, Bokurt S. Epidemiological, Clinical Characteristics and Outcome of Scorpion Envenomation in Batman,Turkey: An Analysis of 120 Cases.

16. Dabo A, Golou G, Traore MS, Diarra N, Goyffon M, Doumbo O. Scorpion envenoming in the North of Mali (West Africa): Epidemiological, clinical and therapeutic aspects. Toxicon. 2011;58(2):154-8.

17. Vazirianzadeh B, Hossienzadeh M, Moravvej SA, Vazirianzadeh M, Mosavi SA. An epidemiological study on scorpion stings in Lordegan County, south-west of Iran. Arch Razi Inst. 2013;68(1):71-6. 
18. Jahan S, Mohammed Al Saigul A, Abdul Rahim Hamed S. Scorpion stings in Qassim, Saudi Arabia-A 5-year surveillance report. Toxicon. 2007;50(2):302-5.

19. Reckziegel GC, Pinto VL. Scorpionism in Brazil in the years 2000 to 2012. J Venomous Anim Toxins Incl Trop Dis. 2014;20(1).

20. Chowell G, Díaz-Dueñas P, Bustos-Saldaña R, Mireles AA, Fet V. Epidemiological and clinical characteristics of scorpionism in Colima, Mexico (2000-2001). Toxicon. 2006;47(7):753-8.

21. Benmosbah M, Guegueniat P, Mayence C, Egmann G, Narcisse E, Gonon S, et al. Epidemiological and clinical study on scorpionism in French Guiana. Toxicon. 2013;73:5662.

22. Pipelzadeh MH, Jalali A, Taraz M, Pourabbas R, Zaremirakabadi A. An epidemiological and a clinical study on scorpionism by the Iranian scorpion Hemiscorpius lepturus. Toxicon. 2007;50(7):984-92.

\section{How to cite this article:}

Yazdanbakhsh K, Kaboudi M, Roghanchi M, Dehghan F, Nooripour R. The effectiveness of acceptance and commitment therapy on Psychological adaptation in women with ms. J. Fundam. Appl. Sci., 2017, 9(1S), 613-622. 